\title{
Reprogramming Immune Cells for Enhanced Cancer Immunotherapy: Targets and Strategies
}

\author{
Yan Dong ${ }^{1}$, Zhuo Wan ${ }^{1}$, Xiaotong Gao ${ }^{1}$, Guodong Yang ${ }^{2 *}$ and Li Liu ${ }^{1 *}$ \\ ${ }^{1}$ Department of Hematology, Tangdu Hospital, Fourth Military Medical University, Xi'an, China, ${ }^{2}$ Department of Biochemistry \\ and Molecular Biology, Fourth Military Medical University, Xi'an, China
}

OPEN ACCESS

Edited by:

Jose A. Garcia-Sanz,

Consejo Superior de Investigaciones

Cientificas (CSIC), Spain

Reviewed by:

Joe Chang

University of Texas MD Anderson

Cancer Center, United States

Masaki Terabe,

National Cancer Institute, National Institutes of Health $(\mathrm{NIH})$,

United States

Nivedita M. Ratnam,

National Cancer Institute

United States, in collaboration with

reviewer MT

*Correspondence:

Guodong Yang

yanggd@fmmu.edu.cn

Li Liu

liuli1@medmail.com.cn

Specialty section:

This article was submitted to Cancer Immunity and Immunotherapy,

a section of the journal

Frontiers in Immunology

Received: 24 September 2020

Accepted: 19 February 2021

Published: 21 April 2021

Citation:

Dong Y, Wan Z, Gao X, Yang G and Liu L (2021) Reprogramming Immune

Cells for Enhanced Cancer

Immunotherapy: Targets and

Strategies.

Front. Immunol. 12:609762.

doi: 10.3389/fimmu.2021.609762
Cancer is one of the leading causes of death and a major public health problem all over the world. Immunotherapy is becoming a revolutionary clinical management for various cancer types. Restoration of aberrant immune surveillance on cancers has achieved markable progress in the past years by either in vivo or ex vivo engineering of the immune cells. Here, we summarized the central roles of immune cells in tumor progression and regression, and the existing and emerging strategies for different immune cell-based immunotherapies. In addition, the current challenges and the potential solutions in translating the immunotherapies into the clinic are also discussed.

Keywords: cancer immune therapy, cell engineering, targets, strategies, immune cells

\section{INTRODUCTION}

Cancer incidence and mortality have been increasing since 2010, making cancer the leading cause of death and a major public health problem all over the world $(1,2)$. The traditional cancer therapies, such as surgery, radiotherapy, and chemotherapy, have difficulty in completely eradicating cancer cells. The emerging immunotherapy is revolutionizing the clinical management of multiple tumors (3).

Tumor microenvironment (TME) is infiltrated by immune cells, which together with stromal cells, contribute to tumor escape from host immune surveillance and its progression $(4,5)$. Generally, the immune cells in TME can be divided into two types: tumor-antagonizing and tumorpromoting immune cells. The tumor-antagonizing immune cells consist of $\mathrm{CD}^{+}$cytotoxic T cells, effector $\mathrm{CD} 4^{+} \mathrm{T}$ cells, natural killer (NK) cells, dendritic cells (DCs), M1-polarized macrophages, and N1-polarized neutrophils. In contrast, the tumor-promoting immune cells mainly consist of regulatory T cells (Tregs) and myeloid-derived suppressor cells (MDSCs). MDSCs could be further divided into two subtypes: the polymorphonuclear MDSCs (PMN-MDSCs) and the monocytic MDSCs (M-MDSCs). The PMN-MDSCs are morphologically similar to N2-polarized neutrophils, whereas M-MDSCs are similar to M2-polarized macrophages. Notably, the role of B cells in TME is relatively unclear and controversial, with both tumor-antagonizing and protumorigenic roles being reported (6).

Aberrant innate and adaptive immune responses are closely related to immunosuppression and tumorigenesis (7). During the early stages of tumor progression, natural killer (NK) cells and CD8 ${ }^{+}$ $\mathrm{T}$ cells act as cytotoxic immune cells to recognize and kill tumor cells (8). However, there remains a subset of less immunogenic tumor cells that survived as the dominant cells afterward, which escaped immune surveillance $(9,10)$. As the tumor continuously grows, different kinds of immune cells adopt various ways to form the immune-suppressive microenvironment, which eventually weakens the tumoricidal effects (11). 
The main mechanism of immunotherapy is to change the tumor microenvironment or the immune cells so that the immune system can achieve the purpose of killing tumors (5). Immunotherapies targeting accessory immune cells are considered as promising strategies against a variety of cancers $(5,11,12)$. Here, we summarize the key roles of different immune cells in the tumor microenvironment and emerging immunotherapy strategies based on modulation of different immune cells. Future challenges and the possible solutions that translate the immunotherapies into clinical reality are also discussed.

\section{CHIMERIC ANTIGEN RECEPTOR T-CELL-BASED IMMUNOTHERAPY}

Malignant progression stimulates adaptive immune responses and creates a subset of specific $\mathrm{T}$ cells that can precisely eliminate tumor cells $(13,14)$. However, with the development of tumors, tumor cells become less immunogenic and lose specific tumor antigens that activate adaptive response at the beginning of malignant progression $(15,16)$. Besides, low expression of class I MHC molecules on tumor cells also leads to the downregulation of $\mathrm{CD}^{+}$cytotoxic $\mathrm{T}$ lymphocytes (CTLs) and thus immunosuppression (17). Immune checkpoints, CTLA-4 and $\mathrm{PD}-1 / \mathrm{PD}-\mathrm{L} 1$ are also blamed to suppress T-cell activity when bound by the corresponding ligands on tumor cells (18-20).

Chimeric antigen receptor (CAR) $\mathrm{T}$ cell technology is an innovative therapy, which harness the inherent capacity of the immune system to fight cancer selectively in an MHCindependent way. CARs are synthetic antigen receptors that include both antigen recognition moieties and T-cell activation signaling domains (21). A CAR consists of three major domains: ectodomain, transmembrane domain, and endodomain $(22,23)$. The ectodomain is exposed to the extracellular space with signal peptide, antigen recognition region, and spacer. The antigen recognition region is usually a single chain variable fragment $(\mathrm{scFv})$ formed by fusing the variable portions of heavy and light chains of a monoclonal antibody with a flexible linker $(24,25)$. The scFv presents the function of identifying and binding tumor antigens with high affinity. A spacer functions as a connection between the antigen-binding domain and the transmembrane domain (26). The transmembrane domain is derived from most of the membrane-proximal components of the endodomain and consists of a hydrophobic alpha helix spanning the membrane, which is related to the stability of the receptor. CD3 $\zeta$ serves as the most common component of the endodomain, which activates $\mathrm{T}$ cells after CAR binds the target antigen. Additionally, the CAR internal domain undergoes intergenerational changes, including one or more costimulatory domains, such as the commonly used CD28 and 41BB, to enhance the persistence and cytotoxicity of CAR-expressing cells $(27,28)$.

Based on the structure of the endodomain, CAR-T cells can be roughly divided into four generations (29). The first generation CARs mimicked the signals from endogenous $\mathrm{T}$-cell receptor (TCR), which contains only one activating domain (usually a portion of the $\zeta$ chain in the TCR complex). Additional activating domains are then added in the next two generations, with more CAR-T-cell proliferation, stronger killing ability, and higher cytokine production. The fourth-generation CARs were typically characterized by the addition of IL-12 to the second generation of CAR-T (30). Currently, CAR-T have been tried to various types of cancer, including leukemia and solid tumors. Moreover, CAR-T could be even engineered to eradicate the cancer stem cells.

\section{CAR-T for Leukemia}

CAR-T immunotherapy has produced a particularly successful clinical response in the treatment of hematologic malignancies. Up to now, three CAR-T cell products have been approved by the U.S. Food and Drug Administration, which all target CD19 antigen. CD19 is a cell-surface component of the B-cell receptor complex involved in B-cell activation, which expressed at high and stable levels on tumor tissue from most patients withB cell acute lymphoblastic leukemia (B-ALL), non-Hodgkin's lymphoma (NHL), and chronic lymphocytic leukemia (CLL). CAR-T cells targeting CD19 have emerged to present a marked efficacy to directly eradicate liquid tumors and induce sustained tumor regression of $\mathrm{B}$ lineage cell malignancies $(31,32)$. It is worth noting that cytokines released by CD19 CAR-T cells also demonstrated the ability to activate both innate and adaptive immune systems and enhance tumor rejection.

Besides CD19-targeted CAR-T, CD22 and CD123 targeted CAR-T were also developed to treat leukemia. CD22-targeted CAR-T cells have a potent antileukemic activity and modest offtarget toxicity (33). Since CD123 is expressed on a range of hematological malignancies, CAR-T targeting CD123 has also a potential role in the prevention of tumor progression and with additional therapeutic effects on eradicating the central nervous system in hematological malignancies (34). In general, all these different targeting CAR-T therapies provide rapid, efficient, and uninhibited regression and destruction of B-cell cancers.

\section{Chimeric Antigen Receptor-T Cell for Solid Tumors}

Besides leukemia, CAR-T-cell therapy has been demonstrated to be effective against several kinds of solid tumors recently, including melanoma, colon cancer, non-small cell lung cancer, ovarian cancer, mesothelioma, and neuroblastoma (35). Mesothelin, epidermal growth factor receptor (EGFR), and human epidermal growth factor receptor 2 (HER2) are the most commonly focused antigen targets in CAR-T therapy to solid malignancies (Table 1).

Mesothelin is a $40-\mathrm{kDa}$ cell-surface glycoprotein. The precursor protein is proteolytically processed into two proteins, a $30-\mathrm{kDa}$ soluble megakaryocyte potentiation factor and a 40-kDa GPI-anchored plasma membrane protein mesothelin (36). Mesothelin is limitedly expressed on mesothelial cells in different types of tissues including pleura, peritoneum, and pericardium but is highly expressed as a tumor-differentiation antigen in a broad spectrum of solid tumors, which make mesothelin as an attractive target for cancer immunotherapy (37). Mesothelin-specific CAR-T-cell therapy also has attracted widespread interest. Commonly, mesothelin-CAR-T-cells consist of anti-mesothelin scFv SS1 fused to TCRzeta signaling and 
TABLE 1 | Engineering strategies for effector chimeric antigen receptor-T (CAR)-T cell.

\begin{tabular}{|c|c|c|}
\hline $\begin{array}{l}\text { Specific } \\
\text { antigens for } \\
\text { engineered } \\
\text { receptors }\end{array}$ & Treated cancer types & Function/effects \\
\hline CD19 & $\begin{array}{l}\text { B-NHL (DLBCL, follicular lymphoma, } \\
\text { mantle cell lymphoma), CLL, B-ALL }\end{array}$ & $\begin{array}{l}\text { Leukemia-specific } \\
\text { targeting }\end{array}$ \\
\hline CD22 & B-ALL & \\
\hline \multirow[t]{2}{*}{ CD123 } & AML & \\
\hline & B-ALL & \\
\hline Mesothelin & $\begin{array}{l}\text { Mesothelioma, TNBC, pancreatic cancer, } \\
\text { lung cancer, gastric cancer, ovarian } \\
\text { cancer, bile duct carcinoma }\end{array}$ & $\begin{array}{l}\text { Cancer-specific } \\
\text { targeting in solid } \\
\text { tumor }\end{array}$ \\
\hline EGFR/EGFRvIII & NSCLC, glioblastoma & \\
\hline HER2 & $\begin{array}{l}\text { Ovarian cancer, breast cancer, } \\
\text { osteosarcoma, HER2-positive sarcoma, } \\
\text { glioblastoma }\end{array}$ & \\
\hline CD133 & $\begin{array}{l}\text { Glioblastoma, lung cancer, breast cancer, } \\
\text { liver cancer, gastric cancer, ovarian cancer, } \\
\text { pancreatic cancer, colorectal cancer, } \\
\text { prostate cancer }\end{array}$ & $\begin{array}{l}\text { Cancer stem } \\
\text { cell-specific } \\
\text { targeting }\end{array}$ \\
\hline \multicolumn{3}{|l|}{ CD90 } \\
\hline \multicolumn{3}{|l|}{ EpCAM } \\
\hline \multicolumn{3}{|l|}{ ALDH } \\
\hline PSCA & Prostate cancer & \\
\hline
\end{tabular}

$A L D H$, aldehyde dehydrogenases; AML, acute myeloid leukemia; B-ALL, acute B lymphoblastic leukemia; B-NHL, B cell non-Hodgkin's lymphoma; CLL, chronic lymphocytic leukemia; DLBCL, diffuse large B-cell lymphoma; EGFR, epidermal growth factor receptor; EGFRVIII, the epidermal growth factor receptor variant III; EpCAM, epithelial cell adhesion molecule; HER2, human epidermal growth factor receptor 2; NSCLC, non-small-cell lung carcinoma; PSCA, prostate stem cell antigen; TNBC, triplenegative breast cancer.

costimulatory domains. There are various clinical studies to investigate the safety and feasibility of mesothelin-specific CAR$\mathrm{T}$ in mesothelioma, lung cancer, breast cancer with pleural metastases (38). All of these trials demonstrated that the application of mesothelin-specific CAR-T-cell therapy is a promising strategy for mesothelin-expressing malignancies.

EGFR is a $170-\mathrm{kDa}$ transmembrane glycoprotein belonging to the ErbB oncogene family of tyrosine kinase receptors. Aberrant activation of EGFR leads to autophosphorylation of receptor tyrosine kinase that ultimately drives cell proliferation and metastasis in various types of tumors (39). Anti-EGFR CAR-T therapy is considered as an alternative way for EGFRoverexpressed solid malignancies (40).

Human epidermal growth factor 2 (HER2) is a membrane tyrosine of the EGFR family. HER2 promotes oncogenesis of several cancers and is found to be amplified in multiple tumors. An $\alpha$ HER2/CD3 RNA-engineered CAR-T-like T cells have achieved success in treating HER2 ${ }^{+}$malignancies (41). Furthermore, HER2-specific CAR-T cells present a prominent effect in targeting and killing HER2-positive cancers such as GBM, ovarian cancer, and breast cancer (42). HER2-specific CAR-T cells along with PD1 blockade was demonstrated to have a significant therapeutic potential for glioblastoma (43).
In addition to preclinical studies, clinical trials also revealed the safety, feasibility, and activity of CAR-T immunotherapy targeting HER2 in patients with advanced biliary tract cancers (BTCs) and pancreatic cancer (PCs) (44).

\section{Chimeric Antigen Receptor-T Cell Targeting Cancer Stem Cells}

Cancer stem cells (CSCs) are a subpopulation of tumor cells that mimic self-renewal and multilineage differentiation capacity of normal tissues and are responsible for maintaining tumor heterogeneity, enhancing tumor growth, therapeutic resistance, immune evasion, invasion, and metastasis (45-47). Thus, specifically targeting CSCs is crucial for developing effective therapeutics. Numerous surface markers expressed on CSCs, namely, CD133, are applied to identify CSCs and thus provide potential targets for CAR-T cell therapy. A study demonstrated that anti-CD133 CAR-T cells efficiently eliminate glioblastoma stem cells in vitro and in vivo (48). Meanwhile, a case report indicated the safety and feasibility of the combination treatment of anti-EGFR CAR-T cells and anti-CD133 CAR-T cells in patients with cholangiocarcinoma (49). Besides CD133, prostate stem cell antigen (PSCA), CD90, EpCAM, and ALDH also can be considered as important target antigens for CAR-T-cell therapy in cancer treatment, which needs further study in both preclinical and clinical settings $(50,51)$.

\section{Challenges and Solutions of Chimeric Antigen Receptor-T Cell Therapy} Adverse Effects

Adverse effects are accompanied by all cancer therapies and sometimes can be a big challenge. The toxicities of CAR-T cell therapy include cytokine release syndrome (CRS), immune effector cell-associated neurotoxicity syndrome (ICANS), cytopenias, and B-cell aplasia (related to CD19 targeting CART cells). CRS and ICANS have emerged as dominant CAR-Tcell-mediated toxicities. The onset of the CRS correlates with T-cell activation and high levels of cytokines, which have no target preference as it can be observed in both CD19 and other novel CARs. The choice of costimulation domain can be a major predictor of toxicity. For 4-1BB incorporated CARs, there were $58 \%$ patients who had CRS of any grade at a median of 5 days from infusion (52). Compared with 4-1BB costimulation domain, incorporation of CD28 leads to more rapid and higher peak expansion of CAR-T cells (53), leading to a 93\% incidence of any grade CRS at a median of 2 days from CAR-T-cell infusion (54). The severity of the CRS is also associated with tumor burden at the time of treatment (55), as heavy tumor burden can provide more stimulation for CAR-T cell expansion. The cause of ICANS remains poorly understood. Potential causes include direct central nervous system toxicity by the CAR-T cells, diffusion of inflammatory cytokines through the blood-brain barrier (BBB), and the dysfunction of the BBB caused by CAR-T cells and/or cytokines.

The safety of CAR-T-cell therapies can be improved by early drug intervention such as using glucocorticoids and tocilizumab, 
an anti-IL6 receptor antagonist, for CRS treatment, and optimal genetic engineering strategies to reduce CAR-T cell toxicity (56).

\section{Low Efficacy in Solid Tumors}

Unlike hematological malignancies, solid tumors present several barriers that affect the safety and clinical outcomes of CART-cell therapy. Target antigen specificity and heterogeneity, lymphocyte trafficking, and tumor-induced immunosuppression are three major factors that hindered the efficacy of CAR-T immunotherapy in solid tumors. Types of approaches are currently explored to address these challenges to enhance treatment efficacy (Table 1).

Selection of an optimal tumor-associated antigen (TAA) is considered as one of the most significant steps for CAR-T targeting. TAA should be highly expressed on all tumor cells but hopefully not expressed on the normal tissues. Although various tumor antigens including neoantigens, oncofetal antigens, and tumor-selective antigens are investigated for CAR-T-cell therapy, there remain no ideal ones meeting the criteria of specificity (57). Another major limitation to TAAs of solid tumors is antigen heterogeneity, which is a variable of the expression of antigen on the cells within a given tumor. To date, employing more targets, targeting multiple tumor antigens at once, and exploring new antigen-activated T-cell killing pathways are three approaches to address the problem of tumor antigen specificity and heterogeneity (58).

Insufficient migration and infiltration to tumor sites is the additional challenge of CAR-T-cell treatment to solid tumors. It is demonstrated that persistence and intratumoral accumulation of CAR-T is inevitably limited after adoptive transfer especially in the liver, lung, and spleen (59). It could be partially attributed to downregulation of cellular adhesion molecules, which inhibits T-cell transmigration. Besides, solid tumors have the capacity of modifying the structure of the adjacent tissue that hinders intratumoral lymphocyte accumulation. Plenty of strategies have been applied to increase lymphocyte migrating and infiltrating to tumor sites (60). Local administration can enhance the accumulation of engineered CAR-T cells at tumor sites and superior control of tumor growth compared with systemic administration, as shown by several preclinical solid tumor models $(61,62)$. Chemokine receptor-ligand interactions plays an important role in mediating endogenous immune cell trafficking. CAR-T cells can be modified to express certain cytokine receptors to enhance trafficking into tumor tissue. For example, expression of a functional CCR2 receptor can enhance tumor localization and tumor eradication of the mesothelinCAR-T cells (63).

Tumor immunosuppressive microenvironment hinders the efficacy of CAR-T therapy even if the $\mathrm{T}$ cell is successfully trafficking the tumor sites. The anatomical structure generated by tumor stroma and the associated high tissue pressure provide natural barriers for CAR-T therapy, while hypoxia and nutrient starvation are two factors of metabolic barriers (64). Limiting the numbers of tumor stroma cells, exposed to a hyperoxia environment, and manipulating key cellular regulators of nutrients, have shown the attractive outcomes to augment antitumor immunity and repress tumor growth
$(65,66)$. Additionally, tumor-derived cytokines, namely, TGF $\beta$, might reduce the antitumor response of CAR-T therapy (67). Theoretically, engineering novel CAR-T cells expressing negative TGF $\beta$ receptor might be beneficial. Furthermore, inhibitory leukocytes like regulatory $\mathrm{T}$ cells, tumor-associated macrophages (TAMs), and myeloid-derived suppressor cells (MDSCs) present as potent barriers of CAR-T therapy $(68,69)$. Reprogramming of the immunosuppressive nature of the TME by genetically engineering CAR-T cells with immune-modulating cytokines is the most commonly used strategy to address this problem, which should be explored in future studies.

\section{Chimeric Antigen Receptor-T-Cell Therapy Resistance}

CAR-T therapy resistance is also a challenge in the field. Various CD19 mutations and alternative splicing have been the dominant cause of CAR-T-cell resistance. In this setting, multivalent targeting CARs or serial manipulation with multiple different CAR-T cells may prevent single-agent resistance. The combination of CD19 and BCMA targeted CAR-T cells, either combined infusion of both anti-CD19 and anti-BCMA CAR-T cells or a tan-CAR with both a scFv-CD19 and scFv-BCMA in tandem orientation, may help to reduce the rate of relapse in the treatment with single scFv-CAR-T cells $(70,71)$. The same strategy can be explored for solid tumors.

Altogether, CAR-T cell therapy has proven to be an inspiring strategy for cancer treatment. Various studies have highlighted that CAR-T cells have achieved encouraging outcomes in various malignancies, while several barriers including the selection of TAA, lymphocyte trafficking, and tumor immunosuppression in solid tumors restrict the effects. There remains much for us to explore to enhance the therapeutic effects of CAR-T cells in cancer treatment (72).

\section{THERAPEUTIC STRATEGIES TARGETING BONE MARROW-DERIVED SUPPRESSOR CELLS}

Bone marrow-derived suppressor cells (MDSCs) consist of a cluster of highly heterogeneous cells generated from myeloid progenitors, which protect a tumor from the immune system and restrain the efficacy of immunotherapy $(73,74)$. The immunosuppressive cytokines caused by tumor-related chronic inflammation induce normal myeloid cell precursors to proliferate and differentiate into MDSCs, which suppress the antitumor effect and promote tumor progression (75). Therefore, targeted numerous enzymes, growth factors, and cytokines regulating the lifecycle of MDSCs may serve as efficient ways to eliminate cancer (76). For instance, neutralizing antibody to KIT significantly reduced MDSC expansion and unleash antitumor efficacy of T cells in colon carcinoma (77). Antagonists of CXCR2 (S-265610) and CXCR4 (AMD3100) altered the recruitment of immature myeloid cells (iMCs) to the tumor and thus reverted the environment that favors tumor progression (78). Besides, anti-IL-6R mAb could eliminate the accumulation of MDSCs, subsequently upregulating IFN $\gamma$ and enhancing 
antitumor T-cell response (79). In summary, eliminating MDSCs is a promising way to unleash immunosuppression in a tumor microenvironment and kill cancer.

\section{THERAPEUTIC STRATEGIES TARGETING TUMOR-ASSOCIATED MACROPHAGES}

Tumor-associated macrophages (TAMs) are the most abundant MDSCs in the TME. They secrete various cytokines, growth factors, chemokines as well as inflammatory mediators that promote key processes in tumor progression (80-82). TAMs function in the processes of angiogenesis, invasion, and metastasis. TAM-induced immunosuppression is mediated by the expression of inhibitory checkpoints, including PD-L1, PDL2, and the non-classical major histocompatibility complex (MHC) class I (MHC-I) molecules (83). Meanwhile, TAMs secrete several cytokines including IL-10, TGF $\beta$, and CCL5, maintaining a strong immunosuppressive microenvironment by inducing regulatory $\mathrm{T}\left(\mathrm{T}_{\text {reg }}\right)$ cell expansion. TAMs also release arginase I to deplete L-arginine, which directly inhibits T-cell cytotoxicity (84).

TAMs exhibit roles of promoting tumor or inhibiting tumor upon different stimuli, which depend on the status of the polarization of macrophage (85). M1-like TAMs accumulating at very early phases of oncogenesis stimulate antitumor immunity and hold the capacity of tumoricidal effect. However, the persistence of M1-like TAMs can induce chronic inflammation, hence, enhancing genomic instability in tumor cells and acts as a driver of oncogenesis in the early oncogenesis (86). Various studies have demonstrated that M2-like TAMs present as the dominant subtype through the progress of "re-education" by contexture changes of immune cells and metabolic factors in $\operatorname{TME}(87,88)$. With the characterization of plasticity and heterogeneity, reprogramming macrophage from M2- to M1-like may provide a viable strategy to eliminate tumor cells $(89,90)$. Accumulating researches are devoted to reversing the pro-tumor effect of TAMs (Table 2).

Currently, depletion, recruitment inhibition, and reprogramming are three commonly used strategies of TAM targeting under clinical trial investigation (91). First, the most advanced approaches of TAM depletion depends on inhibition of colony-stimulating factor 1 and its receptor (CSF1/CSF1R) signaling. CSF1 binds with CSF1R, a class III receptor tyrosine kinase, regulating differentiation, migration, and survival of macrophage and its precursors (92). Various small molecules inhibiting CSF1R tyrosine kinase have been investigated in several researches. Preclinical researches revealed that PLX3397 inhibited tumor-associated microglia and enhances sensitivity to chemotherapy of glioma, c-kit-mutated melanoma, prostate cancer, and classical Hodgkin lymphoma (cHL) (93-95). In addition, CSF1R targeting small molecules, including ARRY-382, PLX7486, BLZ945, and JNJ-40346527, which target the intracellular tyrosine kinase of CSF1R, are in completed or ongoing studies in solid tumors and classical Hodgkin lymphoma (96). Antibodies also play an essential role in targeting CSF1/CSF1R. A study showed that a monoclonal antibody RG7155 strongly reduces TAMs with an increase in T-cell ratio in diffuse-type giant cell tumor patients (97). Furthermore, the compounds MCS110 and PD-0360324 targeting the ligand CSF1 are also found to have the capacity to effectively clear TAMs (95). Compared with the inhibitors of CSF1/CSF1R, bisphosphonates in liposomes seems to be a more directed approach of TAM depletion. Evidence was shown in lung cancer, melanoma, hepatocellular carcinoma, and lung metastasis from breast cancer that bisphosphonates significantly reduced TAM infiltration (98-100). However, there are plenty of side effects remaining in the strategy of TAM depletion. Anti-CSF1R antibodies also non-selectively target non-tumor macrophages with many safety concerns especially accompanied by complications. The increased expression of IFN $\gamma$ and IFN $\alpha$ after CSF1R inhibition directly leads to upregulation of immune checkpoint molecules, such as PD-1 and CTLA-4, possibly restraining its therapeutic effects (101).

Second, blockade of monocyte recruitment to tumors serves as an alternative approach to hinder TAMs, namely, the application of CCL2/CCR2 inhibitors. CCR2, which is highly expressed in monocytes/TAMs, is the only known receptor for chemokine CCL2 (102). It is reported that employing CCR2 antagonist inhibits monocyte/TAM recruitment and M2 polarization in hepatocellular carcinoma (HCC) (102). Carlumab is the most representative CCL2-targeted antibody, which successfully represses macrophage infiltration and thus reduces tumor growth (103). Recently, PF-04136309, a small molecule targeting CCR2, was investigated in a clinical trial of pancreatic cancer, which could enhance sensitivity to chemotherapy (104). However, anti-CCL2/CCR2 therapy might have a notable side effect that the antitumor immune cells might be unable to target the tumors (105). Generally, both depletion and recruitment inhibition present inevitable toxicity and side effects.

Functional reprogramming of TAMs is an attractive way for cancer therapy and holds the capacity of providing an opportunity to rebalance the microenvironment immune infiltrate therapeutically from a pro-tumoral one to an antitumoral one $(92,106,107)$. Anti-CD47 antibodies block the binding of CD47 to SIRP $\alpha$, and thus increase phagocytosis of cancer cells, representing an efficient strategy of TAM reprogramming $(83,108)$. Inhibition of IL-10, a TAM-derived cytokine with the ability to block IL-12 and suppress T-cell tumoricidal function, was identified to improve the efficacy of chemotherapy (109). As Toll-like receptors (TLRs) act a critical role in innate immune response and polarize macrophages into a pro-inflammatory subtype, studies investigate different ligands to change the subtype of TAMs to an antitumoral one (110). The results indicated that agonists of TLR7, TLR8, and TLR9 induced macrophage repolarization and increased tumoricidal activity in several cancers (111-113). Additionally, CD40, a receptor commonly expressed in antigen-presenting cells, interacts with $\mathrm{CD} 40 \mathrm{~L}$ expressed by $\mathrm{T}$ cells to increase pro-inflammatory cytokines. Agonists of CD40/CD40L were identified to affect the protumoral effects in several cancers. Furthermore, strategies targeting crucial processes especially epigenetic regulation in gene expression also obtain effective outcomes to reprogramming TAMs (114). Studies revealed that 
TABLE 2 | In vivo or in vitro engineering strategies for macrophage-based immune therapy.

\begin{tabular}{|c|c|c|c|c|}
\hline Aims & Targets & Delivery strategy & Treated cancer type & Effects/function \\
\hline \multirow[t]{2}{*}{ Recognition } & CD47/SIRP $\alpha$ & Ex vivo and in vivo engineering & $\begin{array}{l}\text { AML, pediatric brain cancer, B cell lymphoma, } \\
\text { lung cancer, ovarian cancer }\end{array}$ & Enhancing phagocytosis \\
\hline & CD40/CD40L & $\begin{array}{l}\text { Activation via drug delivery } \\
\text { (antibody, adenovirus vector) }\end{array}$ & $\begin{array}{l}\text { Melanoma, mesothelioma, pancreatic ductal } \\
\text { adenocarcinoma, }\end{array}$ & $\begin{array}{l}\text { Activating antigen-presenting; substituting } \\
\text { function of CD4+ T cells; apoptosis induction }\end{array}$ \\
\hline \multirow[t]{8}{*}{ Inhibition } & CSF1/CSF1R & $\begin{array}{l}\text { Drug delivery (antibody and } \\
\text { small molecules) }\end{array}$ & $\begin{array}{l}\text { Glioblastoma, tenosynovial giant cell tumors, } \\
\text { Hodgkin lymphoma, colorectal cancer, } \\
\text { fibrosarcoma, breast cancer }\end{array}$ & TAM depletion \\
\hline & Phagocytosis & Delivery of bisphosphonates & $\begin{array}{l}\text { Teratocarcinoma, rhabdomyosarcoma, breast } \\
\text { cancer, lung cancer, melanoma, liver cancer, } \\
\text { prostate cancer }\end{array}$ & \\
\hline & CCL2/CCR2 & $\begin{array}{l}\text { Drug delivery (antibody and } \\
\text { small molecules) }\end{array}$ & $\begin{array}{l}\text { Ovarian cancer, lung cancer, melanoma, } \\
\text { prostate cancer, liver cancer, breast cancer, } \\
\text { pancreatic cancer }\end{array}$ & Blocking TAM recruitment \\
\hline & IL-10 & In vivo delivery of inhibitors & Lung cancer, ovarian cancer & Unleashing expression of IL-12 \\
\hline & DICER & NA & Lung cancer, colorectal cancer & $\begin{array}{l}\text { Enhancing expression of IFN } \gamma \text {-STAT1 and } \\
\text { repolarizing TAMs via miRNA biosynthesis } \\
\text { inhibition }\end{array}$ \\
\hline & HDACs & Delivery of TMP195 & Breast cancer & $\begin{array}{l}\text { Repolarizing TAMs, activating CCL1 and CCL2 } \\
\text { expression via epigenetic remodeling }\end{array}$ \\
\hline & LDHA & NA & Lung cancer & $\begin{array}{l}\text { Downregulation of VEGF and PD-L1; reducing } \\
\text { glycolysis and reversing TAM-driven } \\
\text { immunosuppression }\end{array}$ \\
\hline & $\mathrm{PIK} 3 \gamma$ & In vivo drug delivery (IPI-549) & Lung cancer, head and neck cancer & $\begin{array}{l}\text { Reducing glycolysis and reversing TAM-driven } \\
\text { immunosuppression; upregulation of MHC-II } \\
\text { and IL-12; recruitment of antitumor immune } \\
\text { cells }\end{array}$ \\
\hline Activation & TLRs & Delivery of small molecules & $\begin{array}{l}\text { Melanoma, breast cancer, ovarian cancer, lung } \\
\text { cancer, head and neck cancer, renal cancer, } \\
\text { endometrial cancer, cervical cancer, and types } \\
\text { of leukemia }\end{array}$ & Activation of innate immune response \\
\hline
\end{tabular}

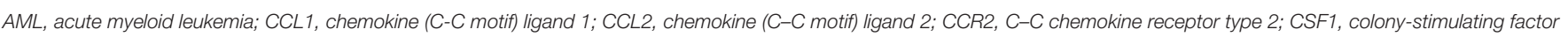

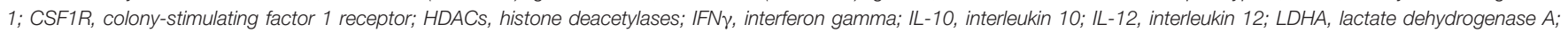

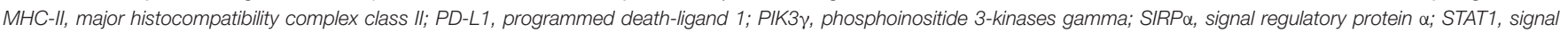
transducer and activator of transcription 1; TAM, tumor-associated macrophage; TLRs, Toll-like receptors; VEGF, vascular endothelial growth factor.

inhibition of DICER, a key enzyme for microRNA synthesis in macrophages switches the subtype accompanied by tumor regression and infiltration of effective immune cells (115). Inhibitors of histone deacetylase (HDACs) can repolarize the phenotype of TAMs and alter CCL1 expression in monocytes (116). Besides, metabolic reprogramming also plays a significant role in functional modifying of TAMs. Deletion of LDHA and inhibition of phosphatidylinositol-4, 5-bisphosphate 3kinase catalytic subunit gamma (PIK3 $\gamma$ ) aimed to reduce glycolysis and hence relieved TAM-driven immunosuppression $(117,118)$. What is more, lactic acid produced by aerobic or anaerobic glycolysis has an essential function in inducing M2-like polarization of TAMs, suggesting the possibilities to reprogram TAMs by suppressing the production of lactic acid (119). However, TAM reprogramming via depleting M2-like TAMs and/or favoring their repolarization toward an M1-like phenotype is limited by innate and acquired resistance, compensation by alternative immunosuppressive cells, and relapse during treatment discontinuation. Besides, side effects including anemia and autoimmunity disease are hard to overcome.
Similar to CAR-T-cell therapy, a recent study engineered the macrophage to express CARs (CAR-Ms) to have antigen-specific phagocytosis capacity, which induced a pro-inflammatory tumor environment, enhanced antitumor T-cell activity, and alleviated tumor burden (120). Another study generated induced pluripotent stem cell (iPSC)-derived, CAR-expressing macrophage cells (CAR-iMac) with antigen-dependent macrophage function and antitumor effects both in vitro and in vivo (121). In general, these studies provided potent strategies for reprogramming tumor microenvironment and set good examples reverting immunosuppression for cancer immunotherapy, though the persistence and efficacy of the CAR macrophage may be further modified.

\section{THERAPEUTIC STRATEGIES TARGETING REGULATORY T CELLS}

Regulatory T (Treg) cells suppress abnormal/excessive immune responses to self- and non-self-antigens to prevent chronic inflammatory, allergic, and autoimmune diseases and maintain 
immune homeostasis $(122,123)$. Infiltration of Treg cells into the TME occurs in various murine and human tumors (124). Treg-induced immune homeostasis can significantly limit the efficacy of antitumor effect as many tumor antigens are either overexpressed or mutated self-antigens. Notably, increasing expression of Tregs regulator forkhead box protein 3 (FOXP3) is identified in many tumors such as breast cancer, melanoma, and pancreatic cancer with a complicated function and cell type-related manner (125). It is reported that FOXP3 plays two key roles: (1) the tumor suppressor in prostate, ovarian, and breast cancers via activating tumor-suppressor genes and inhibiting several oncogenes; (2) a biomarker related with poor prognosis in melanoma, non-small cell lung cancer, urinary bladder cancer, and esophageal cancer (126). Besides, FOXP3 is also involved in immune functions of Tregs via inhibition of APC function mediated by CTLA-4, an increase in immunosuppressive cytokines and metabolites, IL-2 exhaustion (127). There are mainly three strategies to reprogram Treg function based on the immune-suppressive mechanisms of Treg cells (Table 3 ).

High expression of several cell surface receptors makes them attractive targets to selectively deplete Treg cells. Interruption of costimulatory molecule CD28 in Tregs impairs their differentiation and function selectively within tumors, reducing their capacity to suppress antitumor immune responses and promoting tumor control (128). Similarly, targeting surface receptor CD25 successfully represses Treg cells with antitumor immune response (129-131). Moreover, since cytotoxic Tlymphocyte antigen-4 (CTLA4) is expressed by Treg cells and increased after activation of effective $\mathrm{T}$ cells, mAbs targeting CTLA4 was applied to antagonize inhibitory signal and activate effective $\mathrm{T}$ cells to regain tumoricidal activity (132). Other antibodies against GITR, OX40, and molecules predominantly expressed by Treg cells have long been used to selectively deplete Tregs and inhibit their suppressive capacity $(133,134)$. Additionally, blocking chemokine and chemokine receptors (CCL22-CCR4, CCL28-CCR10, and CCL1-CCR8) associated with Treg chemotaxis into TME could reduce the number of Tregs and increase antitumor immune responses (135-137). In murine cancer models, deletion of neuropilin 1 (Nrp-1) specifically in Tregs leads to enhanced immunity to many transplantable tumors (138).

Reprogramming metabolic profiles including glycolysis and lipid oxidation has been considered as another strategy to suppress Treg cells and change the fate of immunotherapy. Recent studies suggest that metabolic regulations are actively involved in Treg differentiation, Foxp3 expression, and Treg stability. Studies showed that inhibiting Akt-mTOR may regulate metabolic programs to facilitate the suppression of Treg cells (139). Besides, low oxygen tension combined with TCR activation, can stabilize hypoxia-inducible factor 1a (HIF1a) and promote Foxp3 expression (140). TLR1 and TLR2 signaling activation in Treg cells enhances Treg glycolysis and proliferation and unleash the immunosuppressive capacity (141). TLR8 signaling selectively inhibits glucose uptake and glycolysis in human Treg cells, resulting in reversal of Treg suppression in melanoma (142).
Modulation of critical factors and chromatin regulators associated with transcription can also transform the function of Treg cells. Foxp3 serves as the most significant transcription factor in Tregs, which is involved in the differentiation and stability of Tregs. Loss of Foxp3 results in autoimmunity in the normal situation, while deficiency of Foxp3 unleashes immunosuppressive capacities and, hence, improves tumoricidal activities $(143,144)$. In addition, epigenetical inhibition of Foxp3 via interruption of histone acetylation [histone acetyltransferase (HAT) EP300] and DNA methylation [ten-eleven translocation (TET)] reduces the immunosuppressive function of Tregs and leaves effective $\mathrm{T}$ cells to regain their antitumor function (145, 146). Foxp3 also regulates Tregs by interacting with other transcription factors; disruption of these factors provides an alternative way to reprogram Tregs with antitumor ability. It is reported that the disruption of the CARMA1-BCL10-MALT1 (CBM) signalosome complex and induction of IFN $\gamma$ secretion suppress Tregs, activate the adaptive immune response, hinder tumor growth, and improve the efficacy of immune checkpoint therapy (147). Moreover, genetic or pharmacologic disruption of transcription factors Eos, Helios, Foxo1/Foxo3, and EZH2 reprograms Tregs to enhance cancer immunity and improve tumoricidal activity (148-151). However, while there is some success through the treatment of targeted Tregs, there are still some obstacles that need to be addressed. First, specific targets for reprogramming Tregs are limited, especially for tumorinfiltrating Tregs. Second, while an immune-related adverse effect resulting from systemic depletion of Treg cells becomes a risk for patients, strategies specifically tuning Treg cell function in TME are needed.

\section{THERAPEUTIC STRATEGIES TARGETING NATURAL KILLER CELLS}

Natural killer (NK) cells, which present in the peripheral blood, lymph nodes, spleen, and bone marrow, are innate immune cells involved in cytotoxicity and cytokine production (152). Tumor necrosis factor alpha (TNF- $\alpha$ ), granulocyte-macrophage colonystimulating factor (GM-CSF), and IFN- $\gamma$ are the main cytokines activated by NK cells (153). In addition, a complicated network of activating and inhibitory receptors regulates the function of $\mathrm{NK}$ cells. C-type lectin receptors (CD94/NKG2C, NKG2D), killer cell C-type lectin-like receptor (NKp65, NKp80), natural cytotoxicity receptors (NKp30, NKp44, and NKp46), SLAM family receptors (2B4, SLAM6, and SLAM7, function in the recognition of hematopoietic cells), Fc receptor Fc $\gamma \mathrm{R}$ (function in antibodydependent cell cytotoxicity), killer cell immunoglobulin-like receptors (KIR) (KIR-2DS and KIR-3DS), DNAM-1, and CD137 (41BB) serve as activating receptors, while KIR-2DL and C-type lectin receptors CD94/NKG2A/B serve as inhibitory receptors of NK cells $(154,155)$. NK cells play an important role in initiating and promoting cancer with effective capacity at the first-line defense for tumor elimination. The major functions of NK include cytotoxicity and cytokine production, which help in killing tumor cells. Higher infiltration of NK cells usually associates with a good prognosis in various cancers. However, 
TABLE 3 | Therapeutic strategies targeting regulatory T cell (Treg) for cancer therapy.

\begin{tabular}{|c|c|c|}
\hline Targets & Treated cancer type & Effects/function \\
\hline $\mathrm{CD} 28^{\star}$ & NA & Inhibiting stability and function of Treg \\
\hline $\mathrm{CD}^{2} 5^{*}$ & Breast cancer & Depleting Treg \\
\hline CTLA4* & Melanoma, colorectal cancer, fibrosarcoma & Depleting CTLA4 expressing Treg through ADCC \\
\hline GITR & Bladder cancer, sarcoma, melanoma, lung cancer & Inhibiting the suppressive activity of Tregs; activating effector T cells \\
\hline OX40\# & $\begin{array}{l}\text { Glioma, breast cancer, colon carcinoma, prostate cancer, sarcoma, } \\
\text { melanoma, lung cancer }\end{array}$ & \\
\hline CCL28/CCR10* & Ovarian cancer & \\
\hline CCL1/CCR8* & Breast cancer & \\
\hline $\mathrm{Nrp1}^{*}$ & Melanoma, CLL, cervical cancer & Preventing Treg recruitment; downregulating VEGF, and producing IFN $\gamma$ \\
\hline Akt-mTOR & Melanoma, ovarian cancer & Increasing glucose uptake and glycolysis; destabilizing Treg \\
\hline TLR1 ${ }^{\#}$ & AML, metastatic colorectal cancer, mantle cell lymphoma & Enhancing Treg glycolysis and proliferation \\
\hline \multicolumn{3}{|l|}{ TET $^{*}$} \\
\hline Foxp3 $^{*}$ & & Inhibiting function of Tregs \\
\hline CBM complex* & Melanoma, colorectal cancer & Enhancing IFN $\gamma$ and suppressing tumor growth \\
\hline Eos $^{*}$ & Lung cancer & $\begin{array}{l}\text { Reprogramming Treg to gain immune-stimulating capacity; decreasing } \\
\text { expression of Foxp3 }\end{array}$ \\
\hline Helios* $^{*}$ & Melanoma, colorectal cancer & Decreasing expression of Foxp3 \\
\hline \multicolumn{3}{|l|}{ Foxo1/Foxo3* } \\
\hline $\mathrm{EZH} 2^{*}$ & & \\
\hline
\end{tabular}

*Inhibition via drug delivery, decoys, siRNA, and others.

\#Activation via mimics or ligands.

ADCC, antibody-dependent cellular cytotoxicity; Akt, protein kinase B; AML, acute myeloid leukemia; CBM complex, CARMA1-BCL10-MALT1 signalosome complex; CCL, chemokine (C-C motif) ligand; CCR, C-C chemokine receptor; CLL, chronic lymphocytic leukemia; CTLA4, cytotoxic T-lymphocyte-associated protein 4; EZH2, enhancer of zeste homolog 2; Foxo1, forkhead box 01; Foxo3, forkhead box O3; Foxp3, forkhead box P3; GITR, glucocorticoid-induced tumor necrosis factor receptor; HAT, histone acetyltransferase; HIF1a, hypoxia-inducible factor 1-alpha; IFNy, interferon gamma; mTOR, mammalian target of rapamycin; Nrp1, neuropilin 1; TET, Ten-eleven translocation methylcytosine dioxygenase; TLRs, toll-like receptors; VEGF, vascular endothelial growth factor.

due to the limited ability of homing and immunosuppressive tumor microenvironment, solid cancers commonly present a poor NK cell infiltration with increasing inhibitory signals. Therefore, targeting with an inhibition signal may serve as a meaningful approach to restore cytotoxic function of NK cells against cancer cells $(154,156,157)$.

To date, NK-cell-based immunotherapy is roughly divided into two types: directly targeting cytokines and receptors involved in NK cell proliferation and function; and chimeric antigen receptor (CAR)-engineered NK cells (Table 4). IL-2 and IL-15 are two of the most commonly employed cytokines in targeting NK cells. IL-2 was applied to produce lymphokineactivated killer (LAK) cells with unsatisfactory outcomes, which is probably attributed to the expansion of Treg cells at the same time. Compared with IL-2, IL-15 met a great success in targeting NK cells for tumor treatment. Expansion of NK cells and CD8 effector memory T cells after IL-15 therapy was identified in both mouse model and clinical studies $(158,159)$. Other cytokines, including IL-18 and IL-21, have also been shown to promote NK cell functions $(158,160)$. What is more, it is worth concerning that a combination therapy of cytokine and other traditional therapy can elevate NK cell proliferation, cytotoxicity, and memory, which is more effective than single cytokine treatment. Additionally, antibodies targeting activating receptors involved in antibody-dependent cell-mediated cytotoxicity (ADCC) can also improve cytotoxicity of NK cells to tumor cells. Similarly, blocking of inhibitory receptors like KIR reverse the suppressive state of NK cells (161).

CAR-NK cell therapy has largely been investigated. CARNK cell therapy exhibits enhanced tumoricidal capacity with advantages that are not responsible for GVHD and do not induce cytokine storms (162). In addition, the sources of CARNK cells can be generated from cord blood (CB), peripheral blood (PB), adult hematopoietic stem cells (HSCs), embryonic stem cells (ESCs), and induced pluripotent stem cells (iPSCs) $(163,164)$. Similar as in CAR-T cells, an intracellular signaling domain-like $\mathrm{CD} 3 \zeta$ and costimulatory signaling domain (CD28, 4-1BB) are basic structures for a CAR. Other molecules like DNAX-activation protein 12 (DAP12), DAP10, and NKG2D can also be selected as intracellular or ectodomain (162). For 
TABLE 4 | Natural killer (NK) cell-based immune therapy.

\begin{tabular}{|c|c|c|c|}
\hline Targeted genes & Delivery strategy & Treated cancer type & Effects/function \\
\hline $\mathrm{IL}-2^{*}$ & Delivery of superkine or fusion protein & AML & $\begin{array}{l}\text { Promoting NK cell proliferation and } \\
\text { activating NK cells }\end{array}$ \\
\hline $\mathrm{IL}-15^{*}$ & Delivery of fusion protein & Ovarian cancer, myeloid leukemia & Enhancing cytotoxicity of NK cells \\
\hline $\mathrm{IL}-18^{*}$ & Delivery of clAP2 and TRAF1 & $\begin{array}{l}\text { Triple-negative breast cancer, lung cancer, } \\
\text { melanoma }\end{array}$ & Sustaining NK cell survival \\
\hline $\mathrm{IL}-21^{*}$ & Delivery of rIL-21 & $\begin{array}{l}\text { Pancreatic cancer, mantle cell lymphoma, } \\
\text { melanoma }\end{array}$ & \\
\hline NKG2D* & Inhibition via antibody & $\begin{array}{l}\text { Lung cancer, colon cancer, prostate cancer, ovarian } \\
\text { cancer, CLL }\end{array}$ & $\begin{array}{l}\text { Triggering cytokine production and NK cell } \\
\text { cytotoxicity }\end{array}$ \\
\hline CD19\# & Ex vivo engineering NK & AML, ALL, multiple myeloma & Specific targeting via the CAR engineered \\
\hline \multicolumn{4}{|l|}{ CD2O\# } \\
\hline HER2\# & & $\begin{array}{l}\text { Neuroblastoma, ovarian cancer, colon cancer, renal } \\
\text { cell cancer, osteosarcoma }\end{array}$ & \\
\hline \multicolumn{4}{|l|}{ EpCAM $^{\#}$} \\
\hline \multicolumn{4}{|l|}{ GD2\# } \\
\hline $\mathrm{PSCA}^{\#}$ & & Prostate cancer & \\
\hline
\end{tabular}

*Inhibition via drug delivery, decoys, siRNA, and others.

\# Recognition targets for ex vivo engineering.

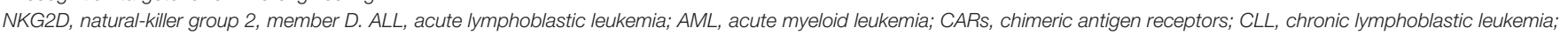
EPCAM, epithelial cell adhesion molecule; HER2, human epidermal growth factor receptor 2; IL, interleukin; PSCA, prostate stem cell antigen.

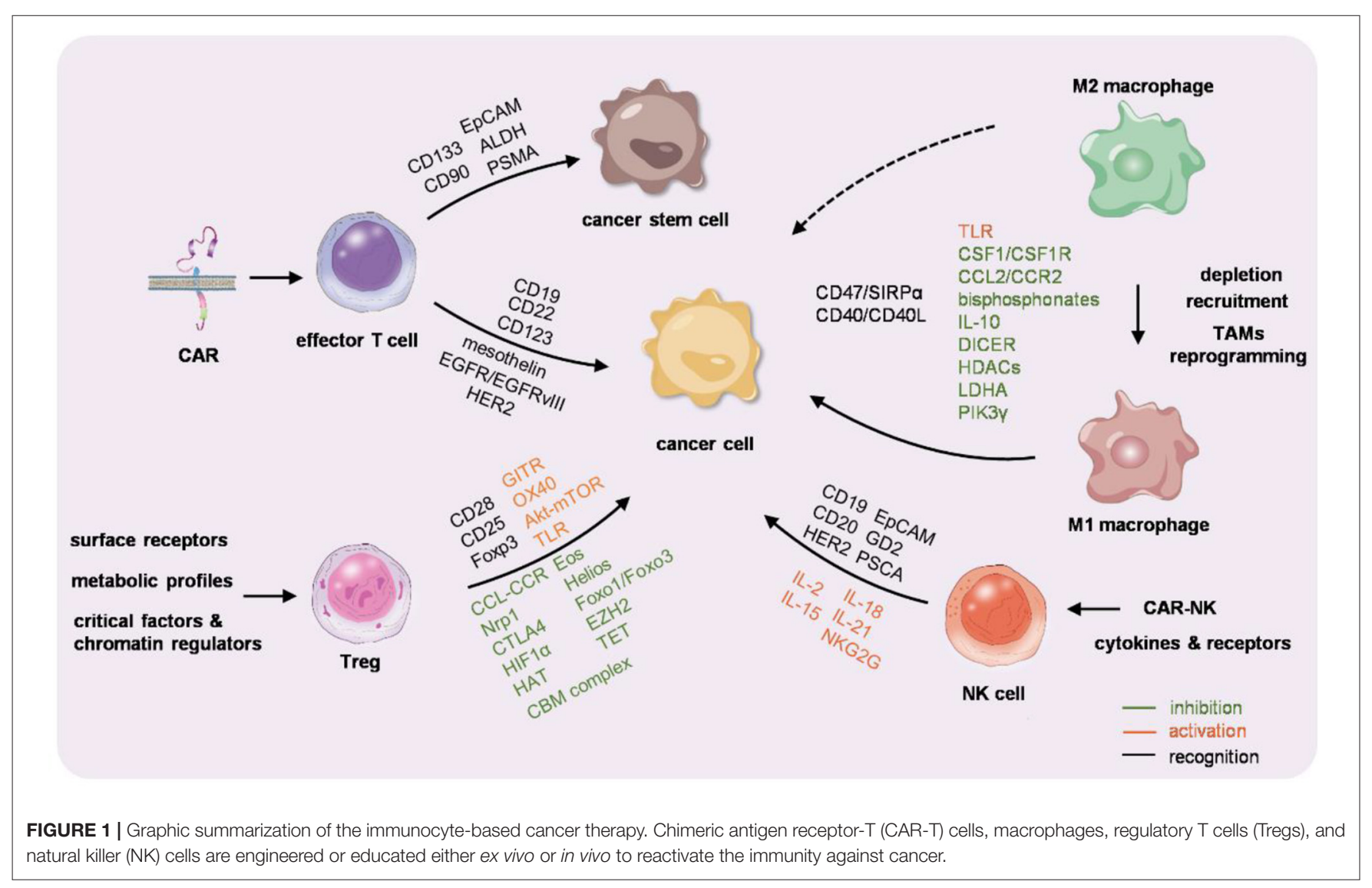

antigen selection, most CAR-NK cells target CD19 and CD20 in hematological malignancies, and HER2, EpCAM, GD2, and PSCA in solid cancers. Recent studies suggested that the most effective responses of CAR-NK cells were observed in ALL, prostate carcinoma, and osteosarcoma, while the effects in other cancers tested were not that satisfactory (165-167). 
To sum up, the development of NK cell-based cancer immunotherapy is a fast-evolving field. Unleashing NK cell antitumor responses by harnessing surface receptors and involved cytokines depict potentially successful immunotherapeutic strategies for cancer. The foremost challenge of CAR-NK cell therapy is expansion of primary NK cells ex vivo. Additionally, limited transfection efficacy in NK cells to express CARs is also notable. Selection of a suitable method, such as viral infection, electroporation, and nanoparticles, is a prerequisite for successful CAR-NK therapy. Although there remain pressing obstacles of CAR-NK cells, the striking outcomes in several cancers make it a promising new strategy for cancer immunotherapy.

\section{CONCLUSIONS AND PERSPECTIVES}

With the advances in the knowledge in the cross-talk between different immune cells and tumor cells, the techniques in cell engineering and drug delivery, and immunotherapies targeting accessory immune cells either ex vivo or in vivo have been intensively studied (Figure 1). Some of them have been widely

\section{REFERENCES}

1. Chen W, Zheng R, Baade PD, Zhang S, Zeng H, Bray F, et al. Cancer statistics in China, 2015. CA Cancer J Clin. (2016) 66:115-32. doi: 10.3322/caac.21338

2. Torre LA, Bray F, Siegel RL, Ferlay J, Lortet-Tieulent J, Jemal A. Global cancer statistics, 2012. CA Cancer J Clin. (2015) 65:87-108. doi: 10.3322/caac.21262

3. Kirkwood JM, Butterfield LH, Tarhini AA, Zarour H, Kalinski P, Ferrone S. Immunotherapy of cancer in 2012. CA Cancer J Clin. (2012) 62:309-5. doi: $10.3322 /$ caac. 20132

4. Gu L, Mooney DJ. Biomaterials and emerging anticancer therapeutics: engineering the microenvironment. Nat Rev Cancer. (2016) 16:56-66. doi: $10.1038 / \mathrm{nrc} .2015 .3$

5. Tang H, Qiao J, Fu YX. Immunotherapy and tumor microenvironment. Cancer Lett. (2016) 370:85-90. doi: 10.1016/j.canlet.2015.10.009

6. Lei X, Lei Y, Li JK, Du WX, Li RG, Yang J, et al. Immune cells within the tumor microenvironment: biological functions and roles in cancer immunotherapy. Cancer Lett. (2020) 470:126-33. doi: 10.1016/j.canlet.2019.11.009

7. Dominguez-Andres J, Netea MG. Long-term reprogramming of the innate immune system. J Leukoc Biol. (2019) 105:329-38. doi: 10.1002/JLB.MR0318-104R

8. Gonzalez H, Hagerling C, Werb Z. Roles of the immune system in cancer: from tumor initiation to metastatic progression. Genes Dev. (2018) 32:126784. doi: 10.1101/gad.314617.118

9. Vinay DS, Ryan EP, Pawelec G, Talib WH, Stagg J, Elkord E, et al. Immune evasion in cancer: mechanistic basis and therapeutic strategies. Sem Cancer Biol. (2015) 35:S185-98. doi: 10.1016/j.semcancer.2015.03.004

10. Ribas A, Adaptive immune resistance: how cancer protects from immune attack. Cancer Discov. (2015) 5:915-9. doi: 10.1158/2159-8290.CD-15-0563

11. Lanza R, Russell DW, Nagy A. Engineering universal cells that evade immune detection. Nat Rev Immunol. (2019) 19:723-33. doi: 10.1038/s41577-019-0200-1

12. Wang H, Mooney DJ. Biomaterial-assisted targeted modulation of immune cells in cancer treatment. Nat Mat. (2018) 17:761-72. doi: 10.1038/s41563-018-0147-9

13. Bantug GR, Galluzzi L, Kroemer G, Hess C. The spectrum of T cell metabolism in health and disease. Nat Rev Immunol. (2018) 18:19-34. doi: $10.1038 /$ nri.2017.99

14. Lim WA, June $\mathrm{CH}$. The principles of engineering immune cells to treat cancer. Cell. (2017) 168:724-40. doi: 10.1016/j.cell.2017.01.016 used in clinics; some have been already under phase $2 / 3$ clinical trial. Generally, immunotherapy is emerging as a promising strategy against a variety of cancers and might be the final therapeutic tool. Translational researches using different strategies for various types of cancers are intensive studies worldwide. Future challenges rely on improvement of the safety, efficacy, and convenience in personalization and customization.

\section{AUTHOR CONTRIBUTIONS}

YD, GY, and LL designed the paper. YD, ZW, XG, GY, and LL analyzed the references and edited the paper. YD and GY wrote the paper. All authors contributed to the article and approved the submitted version.

\section{FUNDING}

This study was funded by the National Natural Science Foundation of China (NSFC 31572344 to LL and NSFC 31771507 to GY) and Shaanxi Provincial Science and Technology Department (2018ZDXM-SF-063) to LL.
15. Schumacher TN, Schreiber RD. Neoantigens in cancer immunotherapy. Science (New York, NY). (2015) 348:69-74. doi: 10.1126/science.aaa4971

16. Yarchoan M, Johnson BA, III, Lutz ER, Laheru DA, Jaffee EM. Targeting neoantigens to augment antitumour immunity. Nat Rev Cancer. (2017) 17:209-22. doi: 10.1038/nrc.2016.154

17. Robbins PF. Tumor-infiltrating lymphocyte therapy and neoantigens. Cancer J (Sudbury, Mass). (2017) 23:138-43. doi: 10.1097/PPO.0000000000000267

18. Rowshanravan B, Halliday N, Sansom DM. CTLA-4: a moving target in immunotherapy. Blood. (2018) 131:58-67. doi: 10.1182/blood-2017-06-741033

19. Constantinidou A, Alifieris C, Trafalis DT. Targeting programmed cell death-1 (PD-1) and ligand (PD-L1): a new era in cancer active immunotherapy. Pharmaco Ther. (2018) 194:84-106. doi: 10.1016/j.pharmthera.2018.09.008

20. Zhang J, Dang F, Ren J, Wei W. Biochemical aspects of PD-L1 regulation in cancer immunotherapy. Trends Biochem Sci. (2018) 12:101432. doi: 10.1016/j.tibs.2018.09.004

21. Gomes-Silva D, Ramos CA. Cancer immunotherapy using car-T cells: from the research bench to the assembly line. Biotechnol J. (2018) 13:1700097. doi: 10.1002/biot.201700097

22. Rahbarizadeh F, Ahmadvand D, Moghimi SM. CAR T-cell bioengineering: single variable domain of heavy chain antibody targeted CARs. Adv Drug Deliv Rev. (2019) 141:41-6. doi: 10.1016/j.addr.2019.04.006

23. Liu J, Zhong JF, Zhang X, Zhang C. Allogeneic CD19CAR-T cell infusion after allogeneic hematopoietic stem cell transplantation in B cell malignancies. J Hematol Oncol. (2017) 10:35. doi: 10.1186/s13045-017-0405-3

24. Ramos CA, Dotti G. Chimeric antigen receptor (CAR)-engineered lymphocytes for cancer therapy. Expert Opin Biol Ther. (2011) 11:855-73. doi: $10.1517 / 14712598.2011 .573476$

25. Getts D, Hofmeister R, Quintas-Cardama A. Synthetic T cell receptor-based lymphocytes for cancer therapy. Adv Drug Deliv Rev. (2019) 141:47-54. doi: 10.1016/j.addr.2019.04.002

26. Maher J, Wilkie S, Davies DM, Arif S, Picco G, Julien S, et al. Targeting of tumor-associated glycoforms of MUC1 with CAR T cells. Immunity. (2016) 45:945-6. doi: 10.1016/j.immuni.2016.10.014

27. Chmielewski M, Hombach AA, Abken H. Of CARs and TRUCKs: chimeric antigen receptor (CAR) $\mathrm{T}$ cells engineered with an inducible 
cytokine to modulate the tumor stroma. Immunol Rev. (2014) 257:83-90. doi: 10.1111/imr.12125

28. Brocker T, Karjalainen K. Signals through T cell receptor-zeta chain alone are insufficient to prime resting T lymphocytes. J Exp Med. (1995) 181:1653-9. doi: $10.1084 / \mathrm{jem} .181 .5 .1653$

29. Cox DBT, Gootenberg JS, Abudayyeh OO, Franklin B, Kellner MJ, Joung J, et al. RNA editing with CRISPR-Cas13. Science (New York, NY). (2017) 358:1019-027. doi: 10.1126/science.aaq0180

30. Sha H-h, Wang D-d, Yan D-l, Hu Y, Yang S-j, Liu S-w, et al. Chimaeric antigen receptor T-cell therapy for tumour immunotherapy. Biosci Rep. (2017) 37:BSR20160332. doi: 10.1042/BSR20160332

31. Sadelain M. CD19 CAR T Cells. Cell. (2017) 171:1471. doi: 10.1016/j.cell.2017.12.002

32. Li X, Ding Y, Zi M, Sun L, Zhang W, Chen S, et al. CD19, from bench to bedside. Immunol Lett. (2017) 183:86-95. doi: 10.1016/j.imlet.2017.01.010

33. Fry TJ, Shah NN, Orentas RJ, Stetler-Stevenson M, Yuan CM, Ramakrishna S, et al. CD22-targeted CAR T cells induce remission in B-ALL that is naive or resistant to CD19-targeted CAR immunotherapy. Nat Med. (2018) 24:20-8. doi: $10.1038 / \mathrm{nm} .4441$

34. Testa U, Pelosi E, Castelli G. CD123 as a therapeutic target in the treatment of hematological malignancies. Cancers. (2019) 11:1358. doi: 10.3390/cancers11091358

35. Guo Y, Wang Y, Han W. Chimeric antigen receptor-modified T cells for solid tumors: challenges and prospects. J Immunol Res. (2016) 2016:3850839. doi: $10.1155 / 2016 / 3850839$

36. Robinson BW, Creaney J, Lake R, Nowak A, Musk AW, de Klerk $\mathrm{N}$, et al. Mesothelin-family proteins and diagnosis of mesothelioma. Lancet (London, England). (2003) 362:1612-6. doi: 10.1016/S0140-6736(03) 14794-0

37. Morello A, Sadelain M, Adusumilli PS. Mesothelin-targeted CARs: driving $\mathrm{T}$ cells to solid tumors. Cancer Discov. (2016) 6:133-46. doi: 10.1158/2159-8290.CD-15-0583

38. O'Hara M, Stashwick C, Haas AR, Tanyi JL. Mesothelin as a target for chimeric antigen receptor-modified $\mathrm{T}$ cells as anticancer therapy. Immunotherapy. (2016) 8:449-60. doi: 10.2217/imt.16.4

39. Tebbutt N, Pedersen MW, Johns TG. Targeting the ERBB family in cancer: couples therapy. Nat Rev Cancer. (2013) 13:663-73. doi: 10.1038/nrc3559

40. Janku F, Stewart DJ, Kurzrock R. Targeted therapy in non-small-cell lung cancer-is it becoming a reality? Nat rev Clin Oncol. (2010) 7:401-14. doi: 10.1038/nrclinonc.2010.64

41. Luo F, Qian J, Yang J, Deng Y, Zheng X, Liu J, et al. Bifunctional alphaHER2/CD3 RNA-engineered CART-like human T cells specifically eliminate HER2(+) gastric cancer. Cell Res. (2016) 26:850-3. doi: 10.1038/cr.2016.81

42. Yu S, Li A, Liu Q, Li T, Yuan X, Han X, et al. Chimeric antigen receptor T cells: a novel therapy for solid tumors. J Hematol Oncol. (2017) 10:78. doi: 10.1186/s13045-017-0444-9

43. Abels ER, Maas SL, Nieland L, Wei Z, Cheah PS, Tai E, et al. Glioblastoma-associated microglia reprogramming is mediated by functional transfer of extracellular miR-21. Cell Rep. (2019) 28:3105-19.e7. doi: 10.1016/j.celrep.2019.08.036

44. Feng K, Liu Y, Guo Y, Qiu J, Wu Z, Dai H, et al. Phase I study of chimeric antigen receptor modified $\mathrm{T}$ cells in treating HER2-positive advanced biliary tract cancers and pancreatic cancers. Protein Cell. (2018) 9:838-47. doi: 10.1007/s13238-017-0440-4

45. Eun K, Ham SW, Kim H. Cancer stem cell heterogeneity: origin and new perspectives on CSC targeting. BMB Rep. (2017) 50:117-25. doi: 10.5483/BMBRep.2017.50.3.222

46. Prager BC, Xie Q, Bao S, Rich JN. Cancer stem cells: the architects of the tumor ecosystem. Cell Stem Cell. (2019) 24:41-53. doi: 10.1016/j.stem.2018.12.009

47. Wang T, Shigdar S, Gantier MP, Hou Y, Wang L, Li Y, et al. Cancer stem cell targeted therapy: progress amid controversies. Oncotarget. (2015) 6:44191-206. doi: 10.18632/oncotarget.6176

48. Gopisetty G, Xu J, Sampath D, Colman H, Puduvalli VK. Epigenetic regulation of CD133/PROM1 expression in glioma stem cells by Sp1/myc and promoter methylation. Oncogene. (2013) 32:3119-29. doi: $10.1038 /$ onc.2012.331
49. Feng KC, Guo YL, Liu Y, Dai HR, Wang Y, Lv HY, et al. Cocktail treatment with EGFR-specific and CD133-specific chimeric antigen receptor-modified $\mathrm{T}$ cells in a patient with advanced cholangiocarcinoma. J Hematol Oncol. (2017) 10:4. doi: 10.1186/s13045-016-0378-7

50. Guo Y, Feng K, Wang Y, Han W. Targeting cancer stem cells by using chimeric antigen receptor-modified $\mathrm{T}$ cells: a potential and curable approach for cancer treatment. Protein Cell. (2018) 9:516-26. doi: 10.1007/s13238-017-0394-6

51. Yu H, Pan J, Guo Z, Yang C, Mao L. CART cell therapy for prostate cancer: status and promise. OncoTargets Ther. (2019) 12:391-5. doi: 10.2147/OTT.S185556

52. Schuster SJ, Bishop MR, Tam CS, Waller EK, Borchmann P, McGuirk JP, et al. Tisagenlecleucel in adult relapsed or refractory diffuse large B-cell lymphoma. N Engl J Med. (2019) 380:45-56. doi: 10.1056/NEJMoa1804980

53. Neelapu SS, Locke FL, Bartlett NL, Lekakis LJ, Miklos DB, Jacobson CA, et al. Axicabtagene ciloleucel CAR T-cell therapy in refractory large B-cell lymphoma. N Engl J Med. (2017) 377:2531-44. doi: 10.1056/NEJMoa1707447

54. Lee DW, Gardner R, Porter DL, Louis CU, Ahmed N, Jensen M, et al. Current concepts in the diagnosis and management of cytokine release syndrome. Blood. (2014) 124:188-95. doi: 10.1182/blood-2014-05-552729

55. Davila ML, Riviere I, Wang X, Bartido S, Park J, Curran K, et al. Efficacy and toxicity management of $19-28 \mathrm{z}$ CAR $\mathrm{T}$ cell therapy in B cell acute lymphoblastic leukemia. Sci Transl Med. (2014) 6:224ra25. doi: $10.1126 /$ scitranslmed. 3008226

56. Perales MA, Kebriaei P, Kean LS, Sadelain M. Reprint of: building a safer and faster CAR: seatbelts, airbags, and CRISPR. Biol Blood Marrow Transplant J Am Soc Blood Marrow Transplant. (2018) 24:S15-9. doi: 10.1016/j.bbmt.2017.12.789

57. Restifo NP, Dudley ME, Rosenberg SA. Adoptive immunotherapy for cancer: harnessing the T cell response. Nat Rev Immunol. (2012) 12:269-81. doi: $10.1038 /$ nri3191

58. Sampson JH, Choi BD, Sanchez-Perez L, Suryadevara CM, Snyder DJ, Flores CT, et al. EGFRvIII mCAR-modified T-cell therapy cures mice with established intracerebral glioma and generates host immunity against tumor-antigen loss. Clin Cancer Res. (2014) 20:972-84. doi: 10.1158/1078-0432.CCR-13-0709

59. Harlin H, Meng Y, Peterson AC, Zha Y, Tretiakova M, Slingluff C, et al. Chemokine expression in melanoma metastases associated with $\mathrm{CD}^{+}$T-cell recruitment. Cancer Res. (2009) 69:3077-85. doi: 10.1158/0008-5472.CAN-08-2281

60. Craddock JA, Lu A, Bear A, Pule M, Brenner MK, Rooney CM, et al. Enhanced tumor trafficking of GD2 chimeric antigen receptor $\mathrm{T}$ cells by expression of the chemokine receptor CCR2b. J Immunother (Hagerstown, Md.: 1997). (2010) 33:780-8. doi: 10.1097/CJI.0b013e3181ee6675

61. Adusumilli PS, Cherkassky L, Villena-Vargas J, Colovos C, Servais E, Plotkin $\mathrm{J}$, et al. Regional delivery of mesothelin-targeted CAR T cell therapy generates potent and long-lasting CD4-dependent tumor immunity. Sci Transl Med. (2014) 6:261 ra151. doi: 10.1126/scitranslmed.3010162

62. Parente-Pereira AC, Burnet J, Ellison D, Foster J, Davies DM, van der Stegen $\mathrm{S}$, et al. Trafficking of CAR-engineered human T cells following regional or systemic adoptive transfer in SCID beige mice. J Clin Immunol. (2011) 31:710-8. doi: 10.1007/s10875-011-9532-8

63. Moon EK, Carpenito C, Sun J, Wang LC, Kapoor V, Predina J, et al. Expression of a functional CCR2 receptor enhances tumor localization and tumor eradication by retargeted human $\mathrm{T}$ cells expressing a mesothelinspecific chimeric antibody receptor. Clin Cancer Res. (2011) 17:4719-30. doi: 10.1158/1078-0432.CCR-11-0351

64. Zhang Y, Ertl HC. Starved and asphyxiated: how can CD8(+) T cells within a tumor microenvironment prevent tumor progression. Front Immunol. (2016) 7:32. doi: 10.3389/fimmu.2016.00032

65. Hatfield SM, Kjaergaard J, Lukashev D, Schreiber TH, Belikoff B, Abbott R, et al. Immunological mechanisms of the antitumor effects of supplemental oxygenation. Sci Transl Med. (2015) 7:277ra30. doi: $10.1126 /$ scitranslmed.aaa1260

66. Jacobs SR, Herman CE, Maciver NJ, Wofford JA, Wieman HL, Hammen JJ, et al. Glucose uptake is limiting in T cell activation and requires CD28mediated Akt-dependent and independent pathways. J Immunol (Baltimore, MD: 1950). (2008) 180:4476-86. doi: 10.4049/jimmunol.180.7.4476 
67. Wallace A, Kapoor V, Sun J, Mrass P, Weninger W, Heitjan DF, et al. Transforming growth factor-beta receptor blockade augments the effectiveness of adoptive T-cell therapy of established solid cancers. Clin Cancer Res. (2008) 14:3966-74. doi: 10.1158/1078-0432.CCR-08-0356

68. Burga RA, Thorn M, Point GR, Guha P, Nguyen CT, Licata LA, et al. Liver myeloid-derived suppressor cells expand in response to liver metastases in mice and inhibit the anti-tumor efficacy of anti-CEA CAR-T. Cancer Immunol Immunother. (2015) 64:817-29. doi: 10.1007/s00262-015-1692-6

69. Gabrilovich DI, Nagaraj S. Myeloid-derived suppressor cells as regulators of the immune system. Nat Rev Immunol. (2009) 9:162-74. doi: $10.1038 /$ nri2506

70. Kang L, Zhang J, Li M, Xu N, Qi W, Tan J, et al. Characterization of novel dual tandem CD19/BCMA chimeric antigen receptor $\mathrm{T}$ cells to potentially treat multiple myeloma. Biomarker Res. (2020) 8:14. doi: 10.1186/s40364-020-00192-6

71. Yan Z, Cao J, Cheng H, Qiao J, Zhang H, Wang Y, et al. A combination of humanised anti-CD19 and anti-BCMA CAR T cells in patients with relapsed or refractory multiple myeloma: a single-arm, phase 2 trial. Lancet Haematol. (2019) 6:e521-9. doi: 10.1016/S2352-3026(19)30115-2

72. Choi BD, Yu X, Castano AP, Bouffard AA, Schmidts A, Larson RC, et al. CAR-T cells secreting BiTEs circumvent antigen escape without detectable toxicity CAR-T cells secreting BiTEs circumvent antigen escape without detectable toxicity. Nat Biotechnol. (2019) 37:1049-58. doi: 10.1038/s41587-019-0192-1

73. Kumar V, Patel S, Tcyganov E, Gabrilovich DI. The nature of myeloid-derived suppressor cells in the tumor microenvironment. Trends Immunol. (2016) 37:208-20. doi: 10.1016/j.it.2016.01.004

74. Tesi RJ. MDSC; the most important cell you have never heard of. Trends Pharmacol Sci. (2019) 40:4-7. doi: 10.1016/j.tips.2018.10.008

75. Yang Z, Guo J, Weng L, Tang W, Jin S, Ma W. Myeloid-derived suppressor cells-new and exciting players in lung cancer. J Hematol Oncol. (2020) 13:10. doi: 10.1186/s13045-020-0843-1

76. Talmadge JE, Gabrilovich DI. History of myeloid-derived suppressor cells. Nat Rev Cancer. (2013) 13:739-52. doi: 10.1038/nrc3581

77. Pan PY, Wang GX, Yin B, Ozao J, Ku T, Divino CM, et al. Reversion of immune tolerance in advanced malignancy: modulation of myeloid-derived suppressor cell development by blockade of stem-cell factor function. Blood. (2008) 111:219-8. doi: 10.1182/blood-2007-04-086835

78. Yang L, Huang J, Ren X, Gorska AE, Chytil A, Aakre M, et al. Abrogation of TGF beta signaling in mammary carcinomas recruits Gr-1+CD11b+ myeloid cells that promote metastasis. Cancer Cell. (2008) 13:23-35. doi: 10.1016/j.ccr.2007.12.004

79. Sumida K, Wakita D, Narita Y, Masuko K, Terada S, Watanabe K, et al. Anti-IL-6 receptor mAb eliminates myeloid-derived suppressor cells and inhibits tumor growth by enhancing T-cell responses. Eur J Immunol. (2012) 42:2060-72. doi: 10.1002/eji.201142335

80. O’Neill LA, Pearce EJ. Immunometabolism governs dendritic cell and macrophage function. J Exp Med. (2016) 213:15-23. doi: $10.1084 /$ jem.20151570

81. Liu M, O'Connor RS, Trefely S, Graham K, Snyder NW, Beatty GL. Metabolic rewiring of macrophages by $\mathrm{CpG}$ potentiates clearance of cancer cells and overcomes tumor-expressed CD47-mediated 'don't-eat-me' signal. Nat Immunol. (2019) 20:265-75. doi: 10.1038/s41590-018-0292-y

82. Pollard JW, Tumour-educated macrophages promote tumour progression and metastasis. Nat Rev Cancer. (2004) 4:71-8. doi: 10.1038/nrc1256

83. Cassetta L, Pollard JW. Targeting macrophages: therapeutic approaches in cancer. Nat Rev Drug Discov. (2018) 17:887-904. doi: 10.1038/nrd.2018.169

84. Noy R, Pollard JW. Tumor-associated macrophages: from mechanisms to therapy. Immunity. (2014) 41:49-61. doi: 10.1016/j.immuni.2014.06.010

85. Tariq M, Zhang J, Liang G, Ding L, He Q, Yang B. Macrophage polarization: anti-cancer strategies to target tumor-associated macrophage in breast cancer. J Cell Biochem. (2017) 118:2484-501. doi: 10.1002/jcb.25895

86. Taniguchi K, Hikiji H, Okinaga T, Hashidate-Yoshida T, Shindou H, Ariyoshi W, et al. Essential role of lysophosphatidylcholine acyltransferase 3 in the induction of macrophage polarization in PMA-treated U937 cells. J Cell Biochem. (2015) 116:2840-8. doi: 10.1002/jcb.25230

87. Tiainen S, Tumelius R, Rilla K, Hamalainen K, Tammi M, Tammi R, et al. High numbers of macrophages, especially M2-like (CD163-positive), correlate with hyaluronan accumulation and poor outcome in breast cancer. Histopathology. (2015) 66:873-3. doi: 10.1111/his.12607

88. Petty AJ, Li A, Wang X, Dai R, Heyman B, Hsu D, et al. Hedgehog signaling promotes tumor-associated macrophage polarization to suppress intratumoral CD8 ${ }^{+}$T cell recruitment. J Clin Investig. (2019) 129:5151-62. doi: 10.1172/JCI128644

89. Huang YK, Wang M, Sun Y, Di Costanzo N, Mitchell C, Achuthan A, et al. Macrophage spatial heterogeneity in gastric cancer defined by multiplex immunohistochemistry. Nat Commun. (2019) 10:3928. doi: 10.1038/s41467-019-11788-4

90. Goossens P, Rodriguez-Vita J, Etzerodt A, Masse M, Rastoin O, Gouirand $\mathrm{V}$, et al. Membrane cholesterol efflux drives tumor-associated macrophage reprogramming and tumor progression. Cell Metab. (2019) 29:1376-89.e4. doi: 10.1016/j.cmet.2019.02.016

91. De Palma M, Lewis CE. Macrophage regulation of tumor responses to anticancer therapies. Cancer Cell. (2013) 23:277-86. doi: 10.1016/j.ccr.2013.02.013

92. Cassier PA, Italiano A, Gomez-Roca CA, Le Tourneau C, Toulmonde $\mathrm{M}$, Cannarile MA, et al. CSF1R inhibition with emactuzumab in locally advanced diffuse-type tenosynovial giant cell tumours of the soft tissue: a dose-escalation and dose-expansion phase 1 study. Lancet Oncol. (2015) 16:949-56. doi: 10.1016/S1470-2045(15)00132-1

93. Coniglio SJ, Eugenin E, Dobrenis K, Stanley ER, West BL, Symons MH, et al. Microglial stimulation of glioblastoma invasion involves epidermal growth factor receptor (EGFR) and colony stimulating factor 1 receptor (CSF-1R) signaling. Mol Med (Cambridge, Mass). (2012) 18:519-27. doi: 10.2119/molmed.2011.00217

94. Yan D, Kowal J, Akkari L, Schuhmacher AJ, Huse JT, West BL, et al. Inhibition of colony stimulating factor-1 receptor abrogates microenvironmentmediated therapeutic resistance in gliomas. Oncogene. (2017) 36:6049-58. doi: 10.1038/onc.2017.261

95. Cannarile MA, Weisser M, Jacob W, Jegg AM, Ries CH, Rüttinger D. Colony-stimulating factor 1 receptor (CSF1R) inhibitors in cancer therapy. $J$ Immunother Cancer. (2017) 5:53. doi: 10.1186/s40425-017-0257-y

96. Butowski N, Colman H, De Groot JF, Omuro AM, Nayak L, Wen PY, et al. Orally administered colony stimulating factor 1 receptor inhibitor PLX3397 in recurrent glioblastoma: an Ivy Foundation Early Phase Clinical Trials Consortium phase II study. Neuro-oncology. (2016) 18:557-64. doi: 10.1093/neuonc/nov245

97. Ries CH, Cannarile MA, Hoves S, Benz J, Wartha K, Runza V, et al. Targeting tumor-associated macrophages with anti-CSF-1R antibody reveals a strategy for cancer therapy. Cancer Cell. (2014) 25:846-59. doi: 10.1016/j.ccr.2014.05.016

98. Qian B, Deng Y, Im JH, Muschel RJ, Zou Y, Li J, et al. A distinct macrophage population mediates metastatic breast cancer cell extravasation, establishment and growth. PLoS ONE. (2009) 4:e6562. doi: 10.1371/journal.pone.0006562

99. Hiraoka K, Zenmyo M, Watari K, Iguchi H, Fotovati A, Kimura YN, et al. Inhibition of bone and muscle metastases of lung cancer cells by a decrease in the number of monocytes/macrophages. Cancer Sci. (2008) 99:1595-02. doi: 10.1111/j.1349-7006.2008.00880.x

100. Gazzaniga S, Bravo AI, A. Guglielmotti, van Rooijen N, Maschi F, Vecchi A, et al. Targeting tumor-associated macrophages and inhibition of MCP-1 reduce angiogenesis and tumor growth in a human melanoma xenograft. $J$ Investig Dermatol. (2007) 127:2031-41. doi: 10.1038/sj.jid.5700827

101. Zhu Y, Knolhoff BL, Meyer MA, Nywening TM, West BL, Luo J, et al. CSF1/CSF1R blockade reprograms tumor-infiltrating macrophages and improves response to T-cell checkpoint immunotherapy in pancreatic cancer models. Cancer Res. (2014) 74:5057-69. doi: 10.1158/0008-5472.CAN-13-3723

102. Li X, Yao W, Yuan Y, Chen P, Li B, Li J, et al. Targeting of tumourinfiltrating macrophages via CCL2/CCR2 signalling as a therapeutic strategy against hepatocellular carcinoma. Gut. (2017) 66:157-67. doi: 10.1136/gutjnl-2015-310514

103. Loberg RD, Ying C, Craig M, Day LL, Sargent E, Neeley C, et al. Targeting CCL2 with systemic delivery of neutralizing antibodies induces prostate cancer tumor regression in vivo. Cancer Res. (2007) 67:9417-24. doi: 10.1158/0008-5472.CAN-07-1286 
104. Nywening TM, Wang-Gillam A, Sanford DE, Belt BA, Panni RZ, Cusworth BM, et al. Targeting tumour-associated macrophages with CCR2 inhibition in combination with FOLFIRINOX in patients with borderline resectable and locally advanced pancreatic cancer: a single-centre, open-label, dosefinding, non-randomised, phase $1 \mathrm{~b}$ trial. Lancet Oncol. (2016) 17:651-2. doi: 10.1016/S1470-2045(16)00078-4

105. Bonapace L, Coissieux MM, Wyckoff J, Mertz KD, Varga Z, Junt $\mathrm{T}$, et al. Cessation of CCL2 inhibition accelerates breast cancer metastasis by promoting angiogenesis. Nature. (2014) 515:130-3. doi: 10.1038/nature13862

106. Arwert EN, Harney AS, Entenberg D, Wang Y, Sahai E, Pollard JW, et al. A unidirectional transition from migratory to perivascular macrophage is required for tumor cell intravasation. Cell Rep. (2018) 23:1239-248. doi: 10.1016/j.celrep.2018.04.007

107. Marra M, Salzano G, Leonetti C, Tassone P, Scarsella M, Zappavigna $\mathrm{S}$, et al. Nanotechnologies to use bisphosphonates as potent anticancer agents: the effects of zoledronic acid encapsulated into liposomes. Nanomed Nanotechnol Biol Med. (2011) 7:955-64. doi: 10.1016/j.nano.2011.03.004

108. Weiskopf K, Ring AM, Ho CC, Volkmer JP, Levin AM, Volkmer AK, et al. Engineered SIRPalpha variants as immunotherapeutic adjuvants to anticancer antibodies. Science (New York, NY). (2013) 341:88-91. doi: $10.1126 /$ science. 1238856

109. Ruffell B, Chang-Strachan D, Chan V, Rosenbusch A, Ho CM, Pryer $\mathrm{N}$, et al. Macrophage IL-10 blocks $\mathrm{CD} 8^{+} \mathrm{T}$ cell-dependent responses to chemotherapy by suppressing IL-12 expression in intratumoral dendritic cells. Cancer Cell. (2014) 26:623-37. doi: 10.1016/j.ccell.2014.09.006

110. El Kasmi KC, Qualls JE, Pesce JT, Smith AM, Thompson RW, HenaoTamayo M, et al. Toll-like receptor-induced arginase 1 in macrophages thwarts effective immunity against intracellular pathogens. Nat Immunol. (2008) 9:1399-406. doi: 10.1038/ni.1671

111. Singh M, Khong H, Dai Z, Huang XF, Wargo JA, Cooper ZA, et al. Effective innate and adaptive antimelanoma immunity through localized TLR7/8 activation. J Immunol (Baltimore, MD: 1950). (2014) 193:4722-31. doi: 10.4049/jimmunol.1401160

112. Le Mercier, Poujol D, Sanlaville A, Sisirak V, Gobert M, Durand I, et al. Tumor promotion by intratumoral plasmacytoid dendritic cells is reversed by TLR7 ligand treatment. Cancer Res. (2013) 73:4629-40. doi: 10.1158/0008-5472.CAN-12-3058

113. Smith DA, Conkling P, Richards DA, Nemunaitis JJ, Boyd TE, Mita AC, et al. Antitumor activity and safety of combination therapy with the Tolllike receptor 9 agonist IMO-2055, erlotinib, and bevacizumab in advanced or metastatic non-small cell lung cancer patients who have progressed following chemotherapy. Cancer Immunol Immunother. (2014) 63:787-96. doi: $10.1007 / \mathrm{s} 00262-014-1547-6$

114. Vonderheide RH. CD40 Agonist antibodies in cancer immunotherapy. Ann Rev Med. (2019) 71:47-58. doi: 10.1146/annurev-med-062518-045435

115. Baer C, Squadrito ML, Laoui D, Thompson D, Hansen SK, Kiialainen A, et al. De palma, suppression of microRNA activity amplifies IFN-gamma-induced macrophage activation and promotes anti-tumour immunity. Nat Cell Biol. (2016) 18:790-802. doi: 10.1038/ncb3371

116. Guerriero JL, Sotayo A, Ponichtera HE, Castrillon JA, Pourzia AL, Schad S, et al. Class IIa HDAC inhibition reduces breast tumours and metastases through anti-tumour macrophages. Nature. (2017) 543:428-32. doi: 10.1038/nature21409

117. Ding J, Karp JE, Emadi A. Elevated lactate dehydrogenase (LDH) can be a marker of immune suppression in cancer: interplay between hematologic and solid neoplastic clones and their microenvironments. Can Biomark A Dis Markers. (2017) 19:353-63. doi: 10.3233/CBM-160336

118. Kaneda MM, Messer KS, Ralainirina N, Li H, Leem CJ, Gorjestani S, et al. PI3Kgamma is a molecular switch that controls immune suppression. Nature. (2016) 539:437-42. doi: 10.1038/nature19834

119. Colegio OR, Chu NQ, Szabo AL, Chu T, Rhebergen AM, Jairam $\mathrm{V}$, et al. Functional polarization of tumour-associated macrophages by tumour-derived lactic acid. Nature. (2014) 513:559-63. doi: 10.1038/nature 13490

120. Klichinsky M, Ruella M, Shestova O, Lu XM, Best A, Zeeman M, et al. Human chimeric antigen receptor macrophages for cancer immunotherapy. Nat Biotechnol. (2020) 38:947-953. doi: 10.1038/s41587-020-0462-y
121. Zhang L, Tian L, Dai X, Yu H, Wang J, Lei A, et al. Pluripotent stem cell-derived CAR-macrophage cells with antigen-dependent anti-cancer cell functions. J Hematol Oncol. (2020) 13:153. doi: 10.1186/s13045-020-00983-2

122. Ohue $Y$, Nishikawa $H$. Regulatory $T$ (Treg) cells in cancer: can Treg cells be a new therapeutic target? Cancer Sci. (2019) 110:2080-9. doi: 10.1111/cas.14069

123. Khattri R, Cox T, Yasayko SA, Ramsdell F. An essential role for scurfin in $\mathrm{CD}^{+} \mathrm{CD} 25^{+} \mathrm{T}$ regulatory cells. Nat Immunol. (2003) 4:337-42. doi: $10.1038 /$ ni909

124. Liu C, Workman CJ, Vignali DA. Targeting regulatory $\mathrm{T}$ cells in tumors. FEBS J. (2016) 283:2731-48. doi: 10.1111/febs.13656

125. Lu L, Barbi J, Pan F. The regulation of immune tolerance by FOXP3. Nat Rev Immunol. (2017) 17:703-17. doi: 10.1038/nri.2017.75

126. Wing JB, Tanaka A, Sakaguchi S. Human FOXP3(+) regulatory $\mathrm{T}$ cell heterogeneity and function in autoimmunity and cancer. Immunity. (2019) 50:302-16. doi: 10.1016/j.immuni.2019.01.020

127. von Boehmer H, Daniel C. Therapeutic opportunities for manipulating $\mathrm{T}(\mathrm{Reg})$ cells in autoimmunity and cancer. Nat Rev Drug Discov. (2013) 12:51-63. doi: $10.1038 / \mathrm{nrd} 3683$

128. Zhang R, Huynh A, Whitcher G, Chang J, Maltzman JS, Turka LA. An obligate cell-intrinsic function for CD28 in Tregs. J Clin Investig. (2013) 123:580-93. doi: 10.1172/JCI65013

129. Foss F. Clinical experience with denileukin diftitox (ONTAK). Sem Oncol. (2006) 33:S11-6. doi: 10.1053/j.seminoncol.2005.12.017

130. Rech AJ, Mick R, Martin S, Recio A, Aqui NA, Powell DJ, et al. CD25 blockade depletes and selectively reprograms regulatory $\mathrm{T}$ cells in concert with immunotherapy in cancer patients. Sci Transl Med. (2012) 4:134ra62. doi: 10.1126/scitranslmed. 3003330

131. Sakaguchi S, Sakaguchi N, Asano M, Itoh M, Toda M. Immunologic self-tolerance maintained by activated $\mathrm{T}$ cells expressing IL-2 receptor alpha-chains (CD25). Breakdown of a single mechanism of self-tolerance causes various autoimmune diseases. J Immunol (Baltimore, MD: 1950). (1995) 155:1151-64.

132. Langhans B, Nischalke HD, Kramer B, Dold L, Lutz P, Mohr R, et al. Role of regulatory $\mathrm{T}$ cells and checkpoint inhibition in hepatocellular carcinoma. Cancer Immunol Immunother. (2019) 65:2055-66. doi: 10.1007/s00262-019-02427-4

133. Schaer DA, Budhu S, Liu C, Bryson C, Malandro N, Cohen A, et al. GITR pathway activation abrogates tumor immune suppression through loss of regulatory T cell lineage stability. Cancer Immunol Res. (2013) 1:320-1. doi: 10.1158/2326-6066.CIR-13-0086

134. Tkachev V, Furlan SN, Watkins B, Hunt DJ, Zheng HB, Panoskaltsis-Mortari A, et al. Combined OX40L and mTOR blockade controls effector T cell activation while preserving Treg reconstitution after transplant. Sci Transl Med. (2017) 9:aan3085. doi: 10.1126/scitranslmed.aan3085

135. Berlato C, Khan MN, Schioppa T, Thompson R, Maniati E, Montfort A, et al. A CCR4 antagonist reverses the tumor-promoting microenvironment of renal cancer. J Clin Investig. (2017) 127:801-13. doi: 10.1172/JCI82976

136. Barsheshet Y, Wildbaum G, Levy E, Vitenshtein A, Akinseye C, Griggs J, et al. CCR8(+)FOXp3(+) Treg cells as master drivers of immune regulation. Proc Natl Acad Sci USA. (2017) 114:6086-91. doi: 10.1073/pnas.1621280114

137. Eksteen B, Miles A, Curbishley SM, Tselepis C, Grant AJ, Walker LS, et al. Epithelial inflammation is associated with CCL28 production and the recruitment of regulatory T cells expressing CCR10. J Immunol (Baltimore, MD: 1950). (2006) 177:593-603. doi: 10.4049/jimmunol.177.1.593

138. Hansen W, Hutzler M, Abel S, Alter C, Stockmann C, Kliche S, et al. Neuropilin 1 deficiency on $\mathrm{CD}^{+} \mathrm{Foxp}^{+}$regulatory $\mathrm{T}$ cells impairs mouse melanoma growth. J Exp Med. (2012) 209:2001-16. doi: $10.1084 /$ jem.20111497

139. Chapman NM, Chi H. mTOR signaling, Tregs and immune modulation. Immunotherapy. (2014) 6:1295-311. doi: 10.2217/imt.14.84

140. Newton R, Priyadharshini B, Turka LA. Immunometabolism of regulatory $T$ cells. Nat Immunol. (2016) 17:618-25. doi: 10.1038/ni.3466

141. Gerriets VA, Kishton RJ, Johnson MO, Cohen S, Siska PJ, Nichols AG, et al. Foxp3 and Toll-like receptor signaling balance Treg cell anabolic metabolism for suppression. Nat Immunol. (2016) 17:1459-66. doi: 10.1038/ni.3577

142. Chen X, Wei M, Liu X, Song S, Wang L, Yang X, et al. Construction and validation of the CRISPR/dCas9-EZH2 system for targeted H3K27Me3 
modification. Biochem Biophys Res Commun. (2019) 511:246-52. doi: 10.1016/j.bbrc.2019.02.011

143. Moreno Ayala MA, Li Z, DuPage M. Treg programming and therapeutic reprogramming in cancer. Immunology. (2019) 157:198-209. doi: $10.1111 /$ imm.13058

144. Allan SE, Song-Zhao GX, Abraham T, McMurchy AN, Levings MK. Inducible reprogramming of human $\mathrm{T}$ cells into Treg cells by a conditionally active form of FOXP3. Eur J Immunol. (2008) 38:3282-9. doi: 10.1002/eji.200838373

145. Yang R, Qu C, Zhou Y, Konkel JE, Shi S, Liu Y, et al. Hydrogen sulfide promotes Tet1- and Tet2-mediated Foxp3 demethylation to drive regulatory $\mathrm{T}$ cell differentiation and maintain immune homeostasis. Immunity. (2015) 43:251-63. doi: 10.1016/j.immuni.2015.07.017

146. Ghosh S, Taylor A, Chin M, Huang HR, Conery AR, Mertz JA, et al. Regulatory T cell modulation by CBP/EP300 bromodomain inhibition. J Biol Chem. (2016) 291:13014-27. doi: 10.1074/jbc.M115.708560

147. Di Pilato M, Kim EY, Cadilha BL, Prussmann JN, Nasrallah MN, Seruggia D, et al. Targeting the CBM complex causes Treg cells to prime tumours for immune checkpoint therapy. Nature. (2019) 570:112-6. doi: 10.1038/s41586-019-1215-2

148. Kim HJ, Barnitz RA, Kreslavsky T, Brown FD, Moffett H, Lemieux $\mathrm{ME}$, et al. Stable inhibitory activity of regulatory $\mathrm{T}$ cells requires the transcription factor Helios. Science (New York, NY). (2015) 350:334-9. doi: $10.1126 /$ science.aad0616

149. Sharma MD, Huang L, Choi JH, Lee EJ, Wilson JM, Lemos H, et al. An inherently bifunctional subset of Foxp3 ${ }^{+} \mathrm{T}$ helper cells is controlled by the transcription factor eos. Immunity. (2013) 38:998-1012. doi: 10.1016/j.immuni.2013.01.013

150. Kerdiles YM, Stone EL, Beisner DR, McGargill MA, Ch'en IL, Stockmann C, et al. Foxo transcription factors control regulatory $\mathrm{T}$ cell development and function. Immunity. (2010) 33:890-904. doi: 10.1016/j.immuni.2010.12.002

151. Wang D, Quiros J, Mahuron K, Pai CC, Ranzani V, Young A, et al. Targeting EZH2 reprograms intratumoral regulatory $\mathrm{T}$ cells to enhance cancer immunity. Cell Rep. (2018) 23:3262-74. doi: 10.1016/j.celrep.2018.05.050

152. Fang F, Xiao W, Tian Z. NK cell-based immunotherapy for cancer. Sem Immunol. (2017) 31:37-54. doi: 10.1016/j.smim.2017.07.009

153. Muntasell A, Ochoa MC, Cordeiro L, Berraondo P, A. Lopez-Diaz de Cerio, et al. Targeting NK-cell checkpoints for cancer immunotherapy. Curr Opin Immunol. (2017) 45:73-81. doi: 10.1016/j.coi.2017.01.003

154. Vivier E, Ugolini S, Blaise D, Chabannon C, Brossay L. Targeting natural killer cells and natural killer $\mathrm{T}$ cells in cancer. Nat Rev. Immunol. (2012) 12:239-52. doi: 10.1038/nri3174

155. Barrow AD, Edeling MA, Trifonov V, Luo J, Goyal P, Bohl B, et al. Natural killer cells control tumor growth by sensing a growth factor. Cell. (2018) 172:534-48.e19. doi: 10.1016/j.cell.2017.11.037

156. Rezvani K, Rouce R, Liu E, Shpall E. Engineering natural killer cells for cancer immunotherapy. Mol Ther J Am Soc Gene Ther. (2017) 25:1769-81. doi: 10.1016/j.ymthe.2017.06.012
157. Pahl J, Cerwenka A. Tricking the balance: NK cells in anti-cancer immunity. Immunobiology. (2017) 222:11-20. doi: 10.1016/j.imbio.2015.07.012

158. Floros T, Tarhini AA. Anticancer cytokines: biology and clinical effects of interferon-alpha2, interleukin (IL)-2, IL-15, IL-21, and IL-12. Sem Oncol. (2015) 42:539-48. doi: 10.1053/j.seminoncol.2015.05.015

159. Pillet AH, Theze J, Rose T. Interleukin (IL)-2 and IL-15 have different effects on human natural killer lymphocytes. Hum Immunol. (2011) 72:1013-7. doi: 10.1016/j.humimm.2011.07.311

160. Srivastava S, Pelloso D, Feng H, Voiles L, Lewis D, Haskova Z, et al. Effects of interleukin-18 on natural killer cells: costimulation of activation through Fc receptors for immunoglobulin. Cancer Immunol Immunother. (2013) 62:1073-82. doi: 10.1007/s00262-013-1403-0

161. Becker PS, Suck G, Nowakowska P, Ullrich E, Seifried E, Bader P, et al. Selection and expansion of natural killer cells for NK cellbased immunotherapy. Cancer Immunol Immunother. (2016) 65:477-84. doi: 10.1007/s00262-016-1792-y

162. Hu Y, Tian ZG, Zhang C. Chimeric antigen receptor (CAR)-transduced natural killer cells in tumor immunotherapy. Acta Pharmacologica Sinica. (2018) 39:167-76. doi: 10.1038/aps.2017.125

163. Shaim H, Yvon E. Cord blood: a promising source of allogeneic natural killer cells for immunotherapy. Cytotherapy. (2015) 17:1-2. doi: 10.1016/j.jcyt.2014.12.001

164. Verneris MR, Miller JS. The phenotypic and functional characteristics of umbilical cord blood and peripheral blood natural killer cells. Br J Haematol. (2009) 147:185-91. doi: 10.1111/j.1365-2141.2009.07768.x

165. Oelsner S, Friede ME, Zhang C, Wagner J, Badura S, Bader P, et al. Continuously expanding CAR NK-92 cells display selective cytotoxicity against B-cell leukemia and lymphoma. Cytotherapy. (2017) 19:235-49. doi: 10.1016/j.jcyt.2016.10.009

166. Romanski A, Uherek C, Bug G, Seifried E, Klingemann H, Wels WS, et al. CD19-CAR engineered NK-92 cells are sufficient to overcome NK cell resistance in B-cell malignancies. J Cell Mol Med. (2016) 20:1287-94. doi: $10.1111 /$ jcmm.12810

167. Zhang C, Burger MC, Jennewein L, Genssler S, Schonfeld K, Zeiner P, et al. ErbB2/HER2-Specific NK cells for targeted therapy of glioblastoma. J Natl Cancer Inst. (2016) 108. doi: 10.1093/jnci/djv375

Conflict of Interest: The authors declare that the research was conducted in the absence of any commercial or financial relationships that could be construed as a potential conflict of interest.

Copyright (c) 2021 Dong, Wan, Gao, Yang and Liu. This is an open-access article distributed under the terms of the Creative Commons Attribution License (CC BY). The use, distribution or reproduction in other forums is permitted, provided the original author(s) and the copyright owner(s) are credited and that the original publication in this journal is cited, in accordance with accepted academic practice. No use, distribution or reproduction is permitted which does not comply with these terms. 